\title{
Diversity of metazoan parasites of the Mozambique tilapia, Oreochromis mossambicus (Peters, 1852), as indicators of pollution in the Limpopo and Olifants River systems
}

\begin{abstract}
Authors:
Grace N. Madanire-Moyo ${ }^{1}$ Wilmien J. Luus-Powell ${ }^{1}$ Pieter A. Olivier ${ }^{1}$

Affiliations:

${ }^{1}$ Department of Biodiversity, University of Limpopo,

South Africa

Correspondence to: Wilmien Luus-Powell

Email:

Wilmien.Powell@ul.ac.za

Postal address

Private Bag X1106, Limpopo

0727, South Africa

Dates:

Received: 28 July 2011

Accepted: 12 Oct. 2011

Published: 16 Feb. 2012

How to cite this article: Madanire-Moyo, G.N., Luus-Powell, W.J. \& Olivier, P.A., 2012, 'Diversity of metazoan parasites of the Mozambique tilapia, Oreochromis mossambicus (Peters, 1852), as indicators of pollution in the Limpopo and Olifants River systems', Onderstepoort Journal of Veterinary Research 79(1), Art. \#362, 9 pages. http:// dx.doi.org/10.4102/ojvr. v79i1.362
\end{abstract}

(C) 2012. The Authors. Licensee: AOSIS OpenJournals. This work is licensed under the Creative Commons Attribution License.
Aquatic systems are affected by a variety of anthropogenic activities that decrease water quality through the introduction of organic and inorganic pollutants. To investigate the relationship between fish parasite communities and water quality, metazoan parasites were examined in 140 specimens of the Mozambique tilapia (Oreochromis mossambicus) sampled in three lakes in the Limpopo Province, namely the Luphephe-Nwanedi Dams (regarded as unpolluted), the Flag Boshielo Dam (regarded as moderately polluted) and a return water dam on a mine site (regarded as polluted). The monogenean parasites Cichlidogyrus halli, digenean larval stages of Clinostomum and Diplostomum spp. and a gryporynchid cestode were found in or on O. mossambicus in all the sampled sites. The distribution of monogeneans (Cichlidogyrus sclerosus, Cichlidogyrus dossoui, Cichlidogyrus tilapiae, Scutogyrus longicornis and three Enterogyrus spp.), metacercarial stages of two digeneans (Neascus and Acanthostomum spp.) and nematodes (an unidentified nematode, Contracaecum sp., Paracamallanus cyathopharynx and Procamallanus laevionchus) was limited to the unpolluted and moderately polluted lakes. Larval stages of Diplostomum sp. were present in O. mossambicus collected from the unpolluted and polluted sites. The variability of the calculated infection indices (prevalence, mean abundance and mean intensity) and the parameters of species richness and diversity suggest that the structure of parasite communities are affected by the pollution levels of the water. The unpolluted reference site had the highest species richness and the highest overall parasite abundance values.

\section{Introduction}

In recent years there has been an increasing awareness that parasitism should be investigated in view of undesirable environmental conditions such as organic and inorganic pollution arising from anthropogenic activities (Marcogliese 2005). Environmental conditions are important for a host's survival and well-being (Sures 2008). A number of studies showed that a close and highly susceptible link exists between environmental conditions and parasitism (Khan \& Billiard 2007; Madanire-Moyo \& Barson 2010; Marcogliese 2005; Marcogliese et al. 2006; Oros \& Hanzelová 2009; Schmidt et al. 2003; Thilakaratne, McLaughlin \& Marcogliese 2007). For heteroxenous (indirect life cycle) metazoan parasites, environmental conditions must be favourable for all host levels (i.e. intermediate and final hosts) and for free-living stages of the parasites (Dzikowski, Paperna \& Diamant 2003). Monoxenous (direct life cycle) metazoans, which are normally ectoparasites, are in constant contact with water, suggesting that poor water quality may adversely affect their diversity to a greater extent (Avenant-Oldewage 2001; Pietrock \& Marcogliese 2003). As a result, populations of both heteroxenous and monoxenous parasites are expected to be affected by changing environmental conditions.

Some approaches for the use of parasites as bioindicators of environmental degradation are identical to those applied for free-living invertebrates (Kennedy 1997) and fishes (Fausch et al. 1990):

- Community data, especially diversity indices, are used to assess environmental health. The underlying hypothesis is that parasite diversity is highest in unpolluted waters, whereas pollution stress leads to a loss of species, change in dominance and reduction in diversity (Blanar et al. 2009). In calculating diversity indices species richness and the abundance of each species are taken into account. The advantage of this approach is that knowledge on the identity of a species, its biology or susceptibility to pollutants is not required. A change in the index can therefore indicate a change in water quality, but it cannot provide any information on the nature of the change or on the identity of the pollutant (Fausch et al. 1990). 
- Another method is the use of multivariate analyses to assess pollution. This technique incorporates a number of factors, but has the disadvantage of requiring more expertise in calculation, and especially in interpretation. Biotic indices are favoured for their low cost and simplicity (Kennedy 1997).

The present study was carried out to ascertain the relationship between metazoan parasite species composition and pollution levels. The Mozambique tilapia, Oreochromis mossambicus (Peters, 1852), was chosen as the model fish because it is a hardy species with a remarkable tolerance for organic (Noorjahan, Dawood \& Nausheen 2003) as well as inorganic pollution (Somanath 2003).

\section{Materials and methods}

Fish were caught in gill nets of mesh sizes $30 \mathrm{~mm}-110 \mathrm{~mm}$ over four seasonal samplings: April 2009 (autumn), July 2009 (winter), October 2009 (spring) and January 2010 (summer). Fish were collected from one reference site and two polluted lakes of the Limpopo and Olifants River systems. The reference site, the Luphephe-Nwanedi Dams $\left(22^{\circ} 39.492^{\prime} \mathrm{S}, 30^{\circ} 25.342^{\prime} \mathrm{E}\right)$, are twin lakes within a 10170 ha nature reserve and are connected by a channel ( $2.5 \mathrm{~m}$ deep). The lakes are relatively unpolluted owing to the absence of intensive agricultural, industrial and mining activities close to the lakes (Oberholster, Ashton \& Macmillan 2009). The moderately polluted site, the Flag Boshielo Dam (24⒋ $4957^{\prime} \mathrm{S}$, $29^{\circ} 24.509^{\prime} \mathrm{E}$ ), is situated in the middle region of the Olifants River, the biggest tributary of the Limpopo River. The Olifants River has been gradually impaired because of an increase in agricultural and mining activities, industrial development and urbanisation (De Villiers \& Mkwelo 2009).

The polluted locality was a return water dam (2359.622'S, $\left.29^{\circ} 24.509^{\circ} \mathrm{E}\right)$ located within mining premises in the Mogalakwena River subcatchment of the Limpopo River. The mine uses sewage effluent from Mokopane's wastewater treatment plant as processing water in its mining operations. The water from the mine's processing plants is pumped to the tailings dam, from where it overflows into the return water dam. The water quality at this locality is affected by industrial, sewage and agricultural activity upstream and mining effluents from the plant.

Examination of sacrificed fish for parasites, fixing, preservation, whole mount preparation and identification of parasites followed standard procedures used by authors such as Douëllou (1993) for monogeneans, Barson et al. (2008) and Chibwana and Nkwengulila (2010) for digeneans, Anderson (1992) for nematodes, Khalil, Jones and Bray (1994) for cestodes and Avenant, Van As and Loots (1989) for Dolops ranarum.

\section{Water quality parameters}

Surface water temperature, dissolved oxygen (DO) content, salinity, $\mathrm{pH}$, conductivity and total dissolved solids (TDS) were determined in situ using a handheld YSI multi-parameter instrument. Subsurface water samples were collected in acidtreated sampling bottles at all sampling sites. Samples were frozen immediately and taken to an accredited laboratory for analyses of selected water parameters (ISO 17025, SANAS, Laboratory no. T0391).

\section{Data analyses}

Levels of parasite infections were analysed according to Bush et al. (1997). Shannon-Wiener and Margalef (diversity), as well as evenness (equal distribution) biotic indices were calculated to compare the three communities of metazoan parasites. Increasing values of the Shannon-Wiener and Margalef indices indicate an increase in diversity. Values of evenness can range from 0 to 1 , with 0 indicating a completely uneven distribution of parasites in a sample and 1 indicating a totally even distribution. All indices were calculated according to Magurran (1988).

All infection data were normalised with $\sqrt{ }(\chi)$ transformations to guarantee normality of distribution. All physical variables were standardised to zero mean and unit variance to make them dimensionless. Principal components analysis (PCA) was performed to determine the pattern of distribution of parasite species amongst the sites. Results were considered significant at the $95 \%$ level $(p<0.05)$. Ordination was achieved using CANOCO version 4 (Ter Braak \& Smilauer 1998).

\section{Ethical considerations}

The protocol was approved by the Animal Ethics Committee of the University of Limpopo. Fish were killed by severing the spinal cord whilst covering the eyes with a damp cloth. Handling and treatment of animals were in accordance with the guidelines of the South African Council on Animal Care (South African Bureau of Standards 2004).

\section{Results Water quality}

Conductivity, total alkalinity, and concentrations of nitrate, sulphate, chloride, potassium, calcium and magnesium were higher in the moderately polluted site and the polluted site, typical of areas receiving sewage input and agricultural, industrial and mining effluents (Table 1). At both sites, levels of heavy metals such as aluminum, iron and lead surpassed the South African target water quality range (TWQR) for aquatic life (Department of Water Affairs and Forestry 1996). Furthermore, the return water dam had the highest concentrations of nutrients (ammonium, nitrate, nitrite and orthophosphate) amongst all sites and were consistently above the levels set by the South African TWQR (Table 1).

The results of the PCA analysis of environmental variables in the three lakes are presented in Figure 1. The first two axes explained $32.7 \%$ of total variation of the environmental characteristics. The Flag Boshielo Dam was positively associated with DO content and iron level but negatively associated with arsenic level (Figure 1). The return water 
TABLE 1: Summary of environmental variables measured in three lakes of the Limpopo and Olifants River systems.

\begin{tabular}{|c|c|c|c|c|c|c|c|c|c|c|c|c|c|}
\hline \multirow[t]{2}{*}{ Variable } & \multicolumn{4}{|c|}{ Luphephe-Nwanedi Dam } & \multicolumn{4}{|c|}{ Flag Boshielo Dam } & \multicolumn{4}{|c|}{ Return water dam } & \multirow[t]{2}{*}{ TWQR } \\
\hline & Mean & \pm s.d. & Min. & Max. & Mean & \pm s.d. & Min. & Max. & Mean & \pm s.d. & Min. & Max. & \\
\hline Temperature & 24.5 & 3.2 & 14.1 & 27.5 & 26.4 & 1.5 & 15.4 & 27.8 & 23.4 & 1.4 & 15.4 & 24.4 & - \\
\hline $\mathrm{pH}$ & 7.4 & 0.2 & 7.2 & 7.6 & 7.9 & 0.7 & 6.2 & 8.8 & 7.1 & 0.3 & 6.8 & 7.4 & $6.5-9.0$ \\
\hline Conductivity (mS/m) & 8.9 & 1.1 & 7.5 & 9.4 & 42.5 & 4.1 & 35.0 & 48.5 & 174.3 & 25.8 & 153.0 & 203.0 & - \\
\hline Turbidity in NTU & 2.3 & 1.2 & 1.2 & 4.0 & 2.0 & 0.9 & 0.6 & 3.7 & 8.3 & 1.8 & 6.4 & 10.0 & - \\
\hline Dissolved oxygen & 7.0 & 0.4 & 6.6 & 7.5 & 7.8 & 1.6 & 4.4 & 9.4 & $5.4 \dagger$ & $1.8 \dagger$ & $3.4 \dagger$ & $6.8 \dagger$ & $6-9$ \\
\hline Total alkalinity & 22.0 & 2.3 & 20.0 & 24.0 & 68.9 & 10.8 & 60.0 & 88.0 & 61.3 & 10.1 & 52.0 & 72.0 & - \\
\hline Ammonium & $<0.2$ & 0.0 & $<0.0$ & $<0.0$ & $<0.2$ & 0.0 & $<0.2$ & $<0.2$ & $0.6 \dagger$ & $0.5 \dagger$ & $0.2 \dagger$ & $1.1 \dagger$ & 0.2 \\
\hline Nitrate & 0.1 & 0.1 & 0.2 & 0.4 & 0.2 & 0.0 & 0.2 & 0.2 & $0.6 \dagger$ & $0.1 \dagger$ & $0.4 \dagger$ & $0.8 \dagger$ & 0.5 \\
\hline Nitrite & 0.1 & 0.0 & 0.1 & 0.1 & $<0.2$ & 0.0 & $<0.2$ & $<0.2$ & $0.25 \dagger$ & $0.1 \dagger$ & $0.3 \dagger$ & $0.4 \dagger$ & 0.29 \\
\hline Orthophosphate & $<0.02$ & 0.00 & $<0.02$ & $<0.02$ & $<0.20$ & 0.20 & $<0.20$ & $<0.20$ & $7.00 \dagger$ & $1.80 \dagger$ & $5.20 \dagger$ & $8.80 \dagger$ & $0.10 \ddagger$ \\
\hline Sulphate $\left(\mathrm{SO}_{4}\right)$ & 5.5 & 0.6 & 5.0 & 6.0 & $111.1 \dagger$ & $4.3 \dagger$ & $105.0 \dagger$ & $116.0 \dagger$ & $581.0 \dagger$ & $68.5 \dagger$ & $527.0 \dagger$ & $658.0 \dagger$ & $100.0 \S$ \\
\hline Chloride (Cl) & 13.5 & 1.0 & 12.0 & 14.0 & 25.1 & 5.0 & 18.0 & 33.0 & 176.0 & 40.8 & 144.0 & 222.0 & 600 \\
\hline Sodium ( $\mathrm{Na}$ ) & 10.8 & 2.1 & 8.0 & 13.0 & 7.2 & 9.3 & 0.4 & 6.82 & 226.3 & 40.3 & 196.0 & 272.0 & 100 \\
\hline Calcium (Ca) & 5.5 & 1.3 & 4.0 & 7.0 & 22.8 & 1.5 & 20.6 & 24.6 & 87.3 & 8.4 & 82.0 & 97.0 & - \\
\hline Magnesium (Mg) & 2.5 & 0.6 & 2.0 & 3.0 & 15.4 & 2.5 & 11.0 & 18.2 & 38.0 & 6.2 & 31.0 & 43.0 & 70.0 \\
\hline Aluminium (Al) & $<0.01$ & 0.00 & $<0.01$ & $<0.01$ & $0.20 \dagger$ & $0.10 \dagger$ & $0.10 \dagger$ & $0.30 \dagger$ & $0.10 \dagger$ & $0.00 \dagger$ & $0.10 \dagger$ & $0.10 \dagger$ & 0.01 \\
\hline Arsenic & $<0.010$ & 0.000 & $<0.010$ & $<0.010$ & 0.003 & 0.000 & 0.003 & 0.003 & $<0.010$ & 0.000 & $<0.010$ & $<0.010$ & 100 \\
\hline Copper & $<0.025$ & 0.00 & $<0.025$ & $<0.025$ & - & - & - & - & $<0.025$ & 0.000 & $<0.025$ & $<0.025$ & 0.500 \\
\hline Iron (Fe) & $<0.025$ & 0.000 & $<0.025$ & $<0.025$ & $0.150 \dagger$ & $0.100 \dagger$ & $0.050 \dagger$ & $0.179 \dagger$ & $<0.025$ & 0.000 & $<0.025$ & $<0.025$ & $0.020 \%$ \\
\hline Lead $(\mathrm{Pb})$ & 0.020 & 0.000 & 0.020 & 0.020 & $0.100 \dagger$ & $0.000 \dagger$ & $0.100 \dagger$ & $0.100 \dagger$ & $0.28 \dagger$ & $0.03 \dagger$ & $0.148 \dagger$ & $0.449 \dagger$ & 0.012 \\
\hline Manganese (Mn) & $<0.025$ & 0.000 & 0.025 & 0.025 & 0.024 & 0.010 & 0.014 & 0.046 & 0.100 & 0.000 & 0.000 & 0.100 & 0.180 \\
\hline Zinc & $<0.025$ & 0.000 & $<0.025$ & $<0.025$ & $<0.01$ & 0.000 & $<0.010$ & $<0.010$ & $<0.025$ & 0.000 & $<0.025$ & $<0.025$ & 1.000 \\
\hline
\end{tabular}

Values are given as averages of four seasonal sampling periods. Unless otherwise indicated, units are in $\mathrm{mg} / \mathrm{L}$.

min., minimum value; max., maximum value; NTU, nephelometric turbidity units; s.d., standard deviation; TWQR, target water quality range for South African aquatic ecosystems.

$\dagger$, Values below (for dissolved oxygen) or above the South African TWQR.

4. Kempster, P.L., Hattingh, W.H.J. \& Van Vliet, H.R., 1980, 'Summarized Water Quality Criteria', technical report (TR 108), Directorate of Water Affairs, Pretoria.

$\S$, Canadian Guidelines (1987) cited by South African National Water Quality Guidelines (1993).

๑, USA: Chiaudini and Premazzi (1988) cited by South African National Water Guidelines (1993).

dam was significantly associated with increasing gradients of nutrients (nitrite, nitrate, sulphate, orthophosphate and ammonium) and inorganic constituents (magnesium, calcium, potassium, chloride, sodium, TDS, conductivity and turbidity). This lake was negatively associated with DO content (Figure 1).

\section{Parasite species composition, diversity and distribution}

A total of 140 specimens of O. mossambicus were collected and examined from the three localities (Table 2). The metazoan parasites encountered included 20 species, comprising eight monogeneans [Cichlidogyrus halli (Price and Kirk, 1967), Cichlidogyrus sclerosus Paperna and Thurston, 1969, Cichlidogyrus dossoui Douëllou, 1993, Scutogyrus longicornis (Paperna and Thurston, 1969), Cichlidogyrus tilapiae Paperna, 1960 and three species of Enterogyrus Paperna, 1963], five larval digeneans (Neascus Von Nordmann, 1832, Tylodelphys Diesing, 1850, Diplostomum Nordmann, 1842, Tetracotyle Diesing, 1858 and Clinostomum Leidy, 1856), four nematodes [Contracaecum Raillet \& Henry, 1912, Procamallanus laevionchus (Wedl, 1862) and Paracamallanus cyathopharynx (Baylis, 1923) and an unidentified nematode larva], a gryporynchid cestode larva, a branchiuran, Dolops ranarum (Stuhlmann, 1891), and a copepod, Ergasilus von Nordmann, 1832 (Table 3).

Mean parasite species richness and diversity indices (Shannon-Wiener, Margalef and Evenness of ShannonWiener) decreased from the reference site to the polluted site. The heteroxenous parasite species corroborated the general pattern seen for diversity indices. The reference site and the moderately polluted site had an equal number of monoxenous parasite species (Table 2). The dominant species were metacercariae of Tetracotyle and Neascus spp. and a gryporynchid cestode at the Luphephe-Nwanedi Dams, the Flag Boshielo Dam and the return water dam, respectively (Table 2).

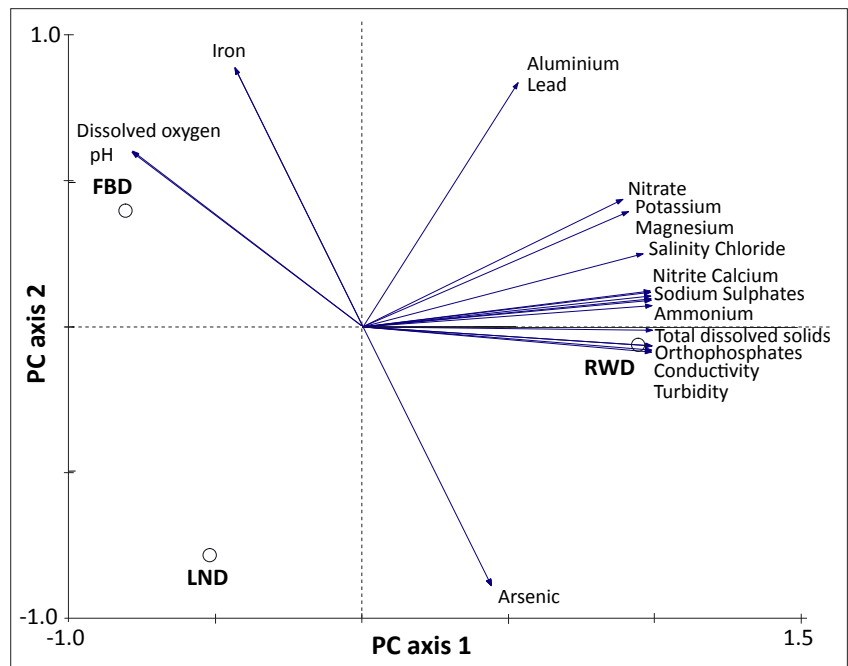

LND, Luphephe-Nwanedi Dams; FBD, Flag Boshielo Dam; PC; principal component; RWD, return water dam.

FIGURE 1: A principal components analysis ordination biplot showing limnological differences amongst the three sampling sites. 
TABLE 2: Some parasitological parameters for metazoan parasites of Oreochromis mossambicus sampled from three lakes of the Limpopo and Olifants River systems.

\begin{tabular}{|c|c|c|c|}
\hline Parameter & Luphephe-Nwanedi Dams & Flag Boshielo Dam & Return water dam \\
\hline Total number of fish & 45 & 48 & 47 \\
\hline Component total number of parasites & 1894 & 912 & 544 \\
\hline Component community species richness & 19 & 16 & 4 \\
\hline Infracommunity mean species richness & $4.3 \pm 1.7$ & $3 \pm 2$ & $1.5 \pm 0.9$ \\
\hline Infracommunity mean parasite individuals & $171.9 \pm 122.2$ & $83.3 \pm 136.1$ & $76.1 \pm 65$ \\
\hline Infracommunity Shannon-Wiener index & $1.4 \pm 0.11$ & $1.21 \pm 0.08$ & $0.95 \pm 0.09$ \\
\hline Infracommunity Margalef & $0.92 \pm 0.06$ & $0.62 \pm 0.03$ & $0.45 \pm 0.02$ \\
\hline Component dominant species & Tetracotyle sp. $(15.7 \%)$ & Neascus sp. $(21.1 \%)$ & Gryporynchid $(82.5 \%)$ \\
\hline Heteroxenous species & 10 & 7 & 3 \\
\hline Monoxenous species & 9 & 9 & 1 \\
\hline $\mathrm{H}_{\mathrm{sp}} / \mathrm{M}_{\mathrm{sp}}$ & 1.1 & 0.7 & 3 \\
\hline
\end{tabular}

$\mathrm{H}_{\mathrm{sp}} / \mathrm{M}_{\mathrm{sp}}$, ratio of heteroxenous to monoxenous species.

TABLE 3: Number and dominance of parasite taxa of Oreochromis mossambicus sampled from three lakes of the Limpopo and Olifants River systems.

\begin{tabular}{|c|c|c|c|c|c|c|}
\hline Taxon & LND & FBD & RWD & Total & Percentage & Rank \\
\hline Cichlidogyrus halli† & 150 & 192 & 3 & 345 & 10.5 & 5 \\
\hline Cichlidogyrus sclerosus & 21 & 61 & - & 82 & 2.5 & 9 \\
\hline Cichlidogyrus dossoui & 24 & 50 & - & 74 & 2.2 & 11 \\
\hline Scutogyrus longicornis & 27 & 37 & - & 64 & 1.9 & 13 \\
\hline Cichlidogyrus tilapiae & 32 & 28 & - & 60 & 1.8 & 15 \\
\hline Enterogyrus sp. 1 & 257 & 113 & - & 370 & 11.2 & 3 \\
\hline Enterogyrus sp. 2 & 35 & 43 & - & 78 & 2.4 & 10 \\
\hline Enterogyrus sp. 3 & 43 & 19 & - & 62 & 1.9 & 13 \\
\hline Neascus sp. & 272 & 123 & - & 395 & 12 & 2 \\
\hline Tylodelphys sp. & 124 & - & - & 124 & 3.7 & 8 \\
\hline Diplostomum sp. & 147 & - & 86 & 233 & 7.1 & 7 \\
\hline Tetracotyle sp. & 299 & - & - & 299 & 9.1 & 4 \\
\hline Clinostomum sp. $\dagger$ & 35 & 25 & 6 & 66 & 2.0 & 12 \\
\hline Nematode (unidentified) & 13 & 21 & - & 34 & 1.0 & 18 \\
\hline Paracamallanus cyathopharynx & 18 & 29 & - & 47 & 1.4 & 16 \\
\hline Procamallanus laevionchus & 30 & 16 & - & 46 & 1.4 & 16 \\
\hline Gryporynchid larva $\dagger$ & 84 & 45 & 449 & 578 & 17.5 & 1 \\
\hline Dolops ranarum & 17 & - & - & 17 & 0.5 & 20 \\
\hline Ergasilus sp. & - & 19 & - & 19 & 0.6 & 19 \\
\hline Total & 1894 & 857 & 544 & 3295 & 100 & - \\
\hline
\end{tabular}

FBD, Flag Boshielo Dam; LND, Luphephe-Nwanedi Dams; RWD, return water dam.

$\dagger$, found at all three sites.

Prevalence values for the monogeneans were greater at the Flag Boshielo Dam than at the Luphephe-Nwanedi Dams, except for Enterogyrus sp. 1 and Enterogyrus sp. 3 (Figure 2a). Prevalence values for metacercariae of a Tylodelphys sp. were relatively similar in fish collected from the Luphephe-Nwanedi Dams and the Flag Boshielo Dam and the same trend was noted for Diplostomum sp. larvae in fish collected from the Luphephe-Nwanedi Dams and the return water dam (Figure $2 b$ ). Prevalence values for all nematodes encountered were higher in fish sampled from the Luphephe-Nwanedi Dams than in fish sampled from the Flag Boshielo Dam (Figure 2c). The prevalence values for the larval stage of the gryporynchid cestode were relatively similar in fish collected from the Luphephe-Nwanedi Dams and the Flag Boshielo Dam, but highest in fish collected from the return water dam (Figure $2 \mathrm{~d}$ ).

The mean abundance values for all monogeneans encountered were higher in the Luphephe-Nwanedi Dams than in the
Flag Boshielo Dam (Figure 3a). The mean abundance values for metacercariae of Clinostomum sp. were relatively low in fish collected from all localities (Figure 3b). Larvae of the unidentified nematode and $P$. cyathopharynx were more abundant in the Flag Boshielo Dam than in the LuphepheNwanedi Dams (Figure 3c). The gryporynchid cestode larvae were most abundant in fish from the return water dam (Figure 3d). The mean intensity values for most metazoan parasites were highest at the Luphephe-Nwanedi Dams, except for species such as C. halli, C. sclerosus, Enterogyrus sp. 2, P. cyathopharynx and the larvae of the gryporynchid cestode (Figures $4 a-d)$.

The eight most dominant parasite species from O. mossambicus comprised $80.7 \%$ of the total individual parasite specimens encountered (Table 3). The proportional abundance of the six main taxonomic groups collected during the study revealed that metacercariae of digeneans and larval cestodes were more cosmopolitan than monogeneans (Figure 5). 


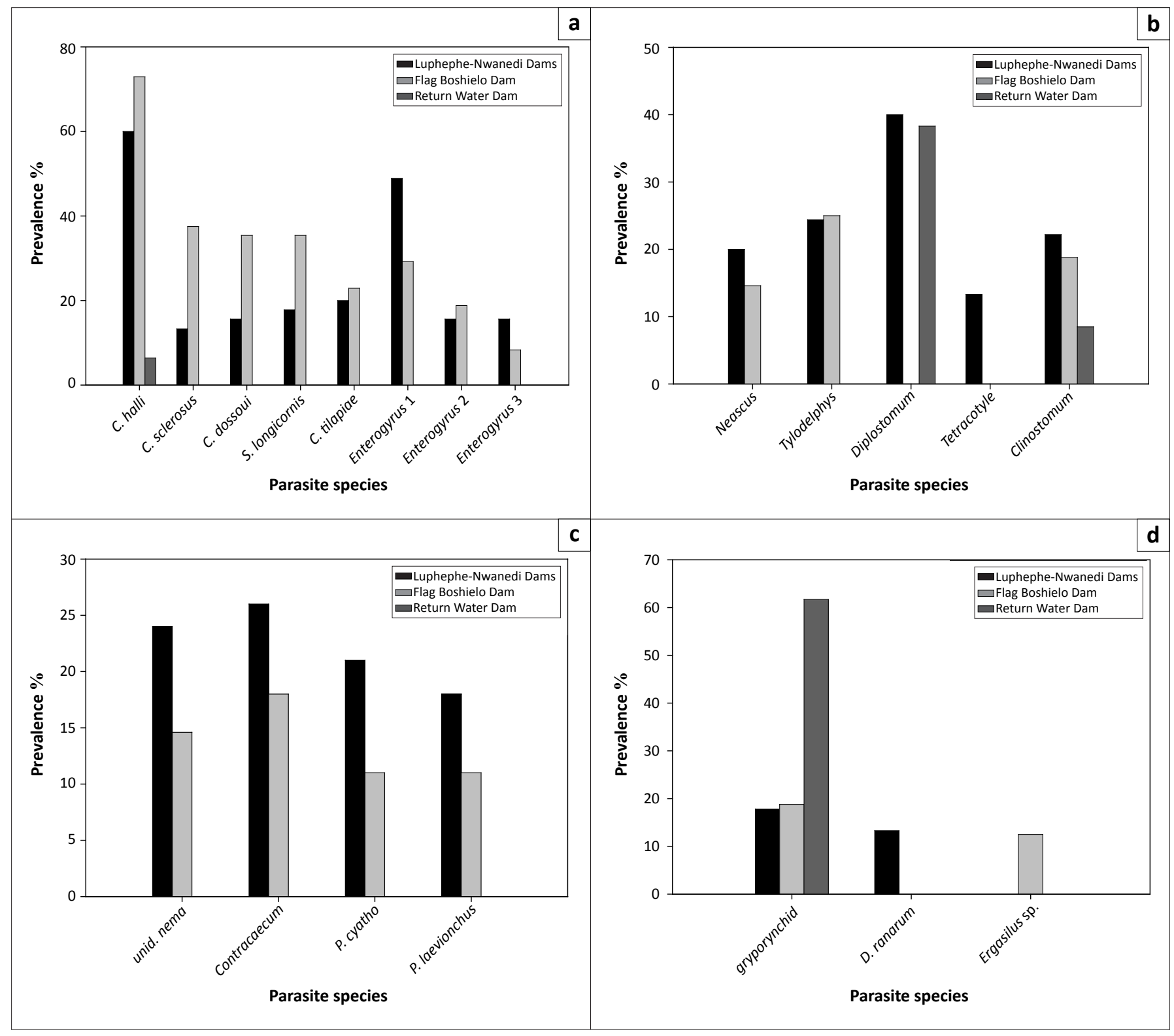

C., Cichlidogyrus spp.; P. cyatho., Paracamallanus cyathopharynx; S., Scutogyrus sp.; unid. nema., larvae of unidentified nematode; D., Dolops.

FIGURE 2: Prevalence of (a) monogeneans, (b) digeneans, (c) nematodes and (d) gryporynchid cestode larvae, Dolops ranarum and Ergasilus sp., of fish sampled from the Limpopo and Olifants River systems.

The first two factors in the PCA accounted for $36.2 \%$ of the observed variance, which was based on the relative abundance of the parasite species (Figure 6). All monogeneans, metacercariae of the digeneans (Clinostomum and Neascus spp.) and the nematodes were closely associated with O. mossambicus sampled from the Luphephe-Nwanedi Dams and the Flag Boshielo Dam. D. ranarum, metacercariae of Tylodelphys and Tetracotyle spp. were unique to the Luphephe-Nwanedi Dams whilst larvae of Diplostomum sp. were common in the Luphephe-Nwanedi Dams and the return water dam. The gryporynchid cestode larvae were, to a greater extent, strongly associated with the return water dam (Figure 6).

\section{Discussion}

The spatial distribution of water quality variables showed the pollution gradient differed amongst the sampling sites (return water dam < Flag Boshielo Dam < Luphephe-Nwanedi Dams), especially for trophic status variables (ammonia, nitrates, nitrites, orthophosphates and sulphates), turbidity, conductivity, TDS and metals (lead and aluminium). The Luphephe and Nwanedi tributaries flow through areas of natural grassland, interspersed with areas of subsistence cultivation. There is very little urbanisation; as a result, the waters are relatively uncontaminated. Results from this study were consistent with previous work describing the Luphephe-Nwanedi Dams as essentially unpolluted (Oberholster et al. 2009) and the Flag Boshielo Dam as impacted by a combination of mining and agricultural effluents (Ashton 2010; De Villiers \& Mkwelo 2009). The results further demonstrate that the return water dam is a polluted site, with high levels of nutrients and metals.

Parasite communities at the polluted and reference sites showed some trends consistent with predicted parasite 


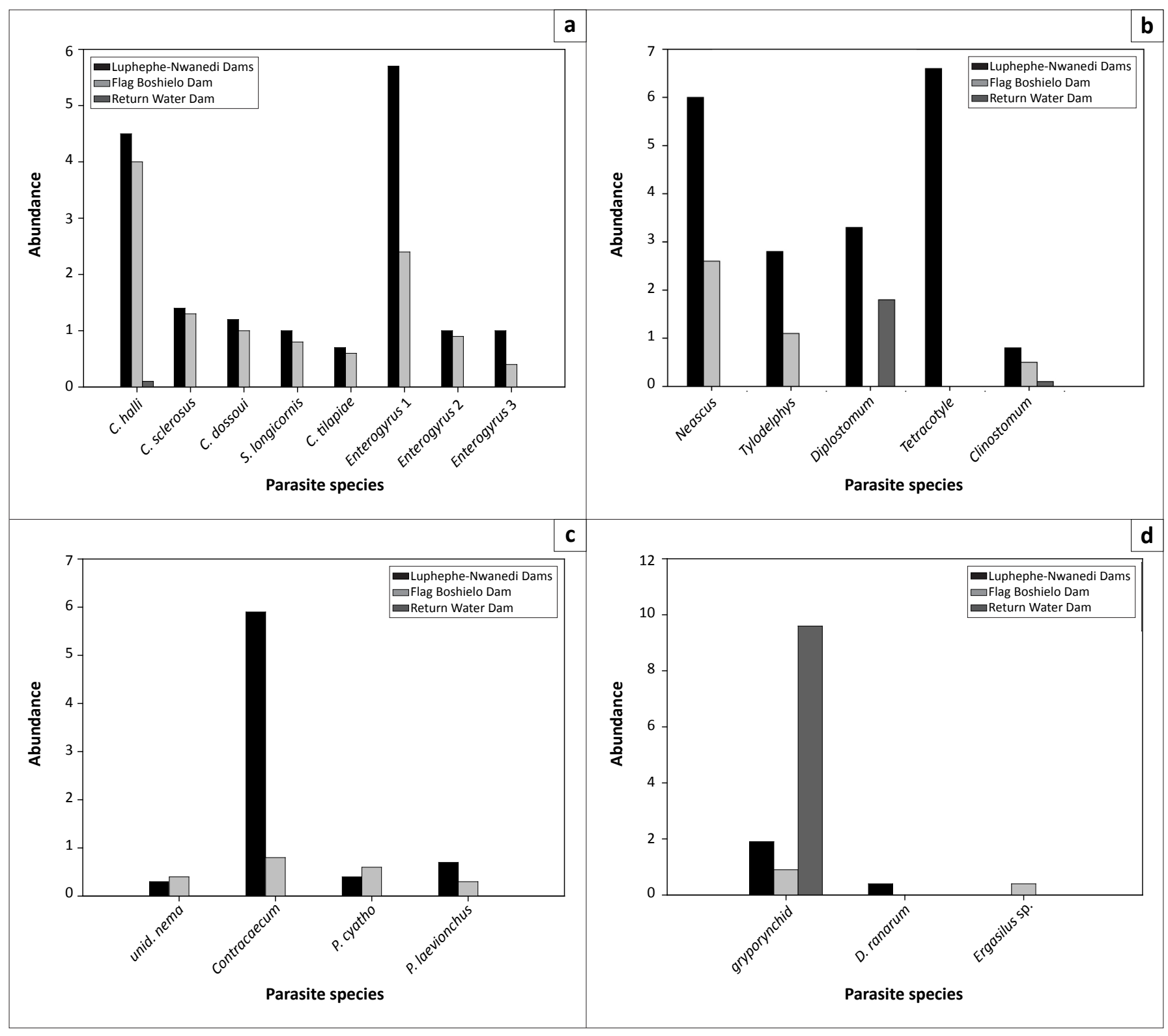

C., Cichlidogyrus spp.; P. cyatho., Paracamallanus cyathopharynx; S., Scutogyrus sp.; unid. nema., larvae of unidentified nematode; D., Dolops.

FIGURE 3: Mean abundance of (a) monogeneans, (b) digeneans, (c) nematodes and (d) gryporynchid cestode larvae (Dolops ranarum and Ergasilus sp.) of fish sampled from three lakes of the Limpopo and Olifants River systems.

diversity in stressed environments (Blanar et al. 2009). The reference site had the highest species richness and the highest overall parasite abundances. Similar to the polluted site, the moderately polluted site had lower mean abundance and mean intensity values for most parasite species than the reference site. In addition, these two sites revealed a total absence of the branchiuran $D$. ranarum and metacercariae of Tylodelphys and Tetracotyle spp. Fish from the polluted site had the lowest total parasite numbers, species richness and parasite diversity as reflected by the indices used in the present study.

Decreases in species richness and diversity in the helminth parasite communities of fishes can indeed result from aquatic pollution (Marcogliese 2005). This naturally occurs through the loss of ectoparasitic monoxenous species that are in direct contact with organic and inorganic pollutants (Pietrock
\& Marcogliese 2003) or through the loss of heteroxenous parasites that use intermediate hosts sensitive to pollution (Marcogliese 2005; Pietrock, Meinelt \& Marcogliese 2008). For example, the ectoparasites C. halli, C. sclerosus, C. dossoui, C. tilapiae, S. longicornis, D. ranarum and Ergasilus sp. seem to be sensitive to pollution as they were not found in the polluted site. Although the three Enterogyrus spp. are endoparasitic, they were also absent from the polluted site, demonstrating their sensitivity to pollution. Metacercariae stages of the digeneans (Neascus, Tylodelphys and Tetracotyle spp.) and the nematodes (unidentified nematode, Contracaecum sp., P.cyathopharynx and P. laevionchus) were absent at the polluted site, indicating their possible intolerance to pollution.

These patterns in parasite communities are consistent with several similar studies of substantially disturbed environments (Dzikowski et al. 2003; Khan \& Billiard 


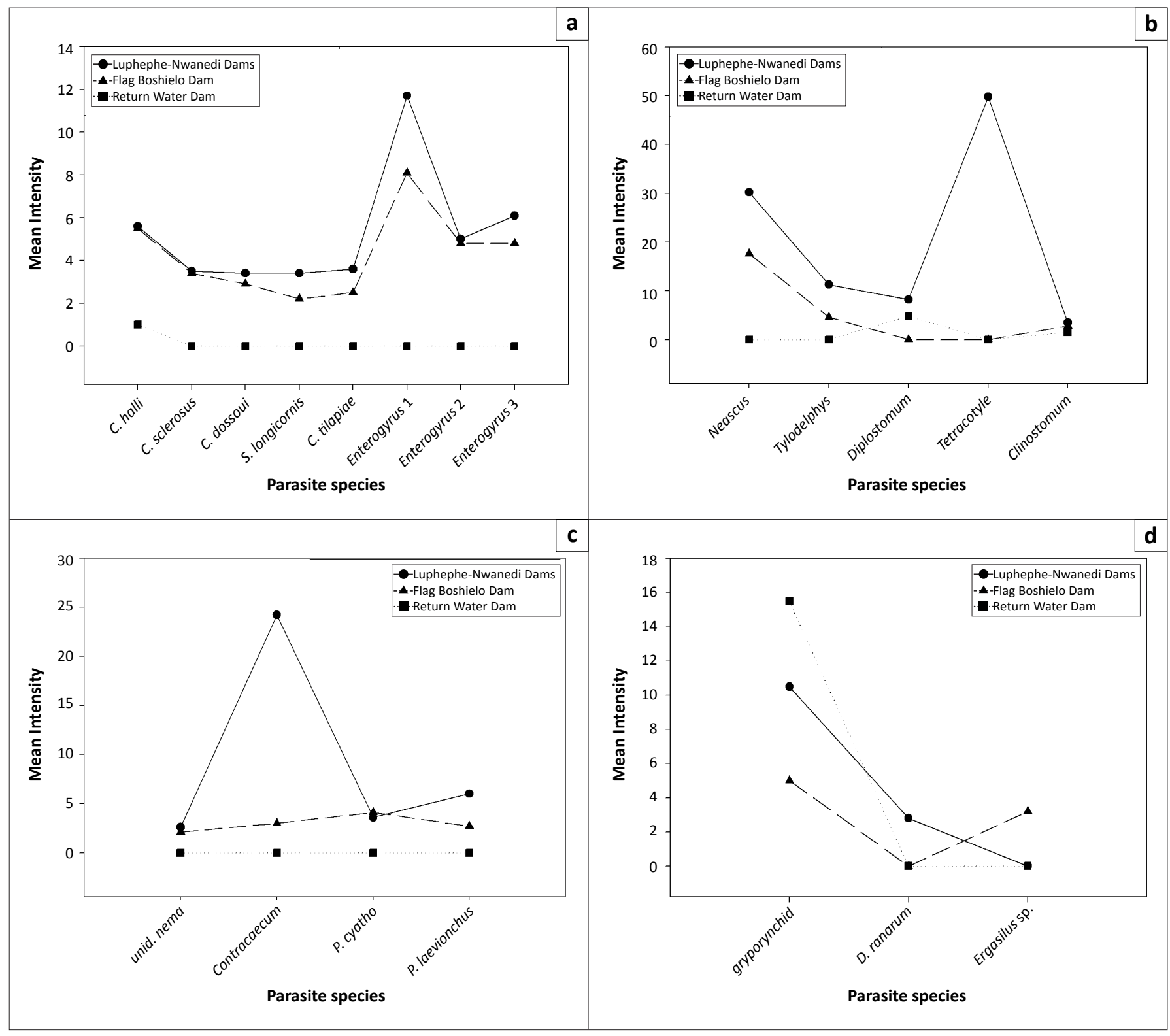

C., Cichlidogyrus spp.; P. cyatho., Paracamallanus cyathopharynx; S., Scutogyrus sp.; unid. nema., larvae of unidentified nematode; D., Dolops.

FIGURE 4: Mean intensity of (a) monogeneans, (b) digeneans, (c) nematodes and (d) gryporynchid cestode larvae (Dolops ranarum and Ergasilus sp.) of fish sampled from three lakes of the Limpopo and Olifants River systems.

2007; Madanire-Moyo \& Barson 2010; Marcogliese 2005; Marcogliese et al. 2006; Oros \& Hanzelová 2009; Schmidt et al . 2003; Thilakaratne et al. 2007). For example, indirect life cycle helminth parasites that were present in a nearby reference estuary were missing from the parasite communities of the grey mullet (Liza aurata and Liza ramada) collected from a nearby polluted estuary (Dzikowski et al. 2003).

Exposure to urban effluent was reflected in lower species richness of macroparasite communities of the flounder fish (Platichthys flesus) in German Blight in the North Sea (Schmidt et al. 2003). Marcogliese et al. (2006) established that fish downstream of sewage outfall had lower total parasite abundances than fish collected from reference localities in Lake St. Louis. Thilakaratne et al. (2007) reported a lower diversity of helminths at sewage effluent and metalpolluted sites than at a reference site in Lake St. Louis.
Winter flounder (Pleuronectes americanus) in the vicinity of a pulp and paper mill had significantly lower abundances of intestinal helminths than those at a nearby reference locality (Khan \& Billiard 2007). A fish community in a river in southern Slovakia, polluted with cyanide and heavy metals, had half the diversity of gastrointestinal helminth parasites as a comparable community in a nearby reference river owing to a loss of species that exploit sensitive invertebrate species as obligatory intermediate hosts (Oros \& Hanzelová 2009). Component species richness and diversity of parasites of the sharptooth catfish (Clarias gariepinus), decreased with organic pollution in the Manyame catchment of Zimbabwe (Madanire-Moyo \& Barson 2010).

The gryporynchid cestode larvae were evidently associated with the polluted site. The first intermediate hosts of most cestodes are oligochaetes and these worms can tolerate 


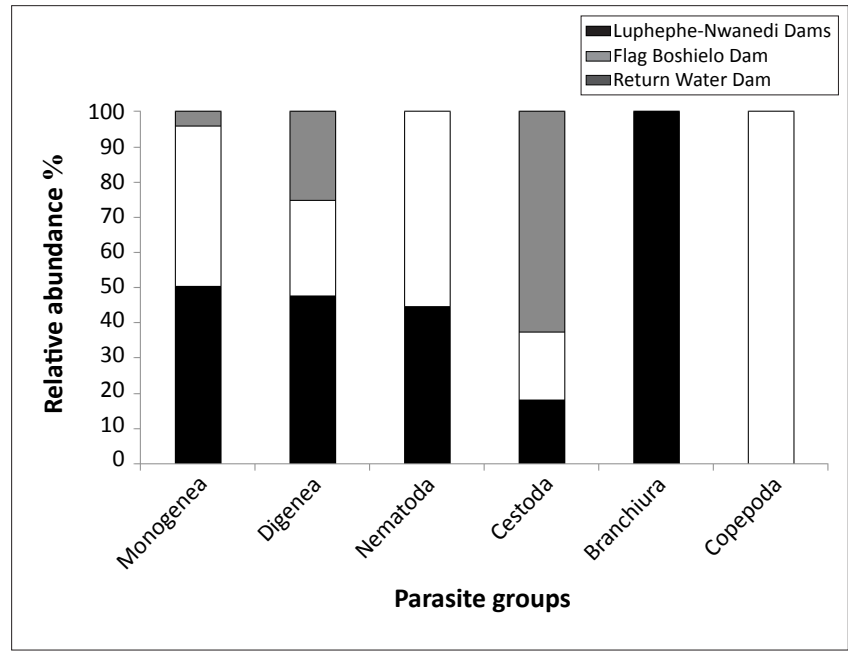

FIGURE 5: Relative abundance of parasite groups in Oreochromis mossambicus sampled from three lakes of the Limpopo and Olifants River systems.

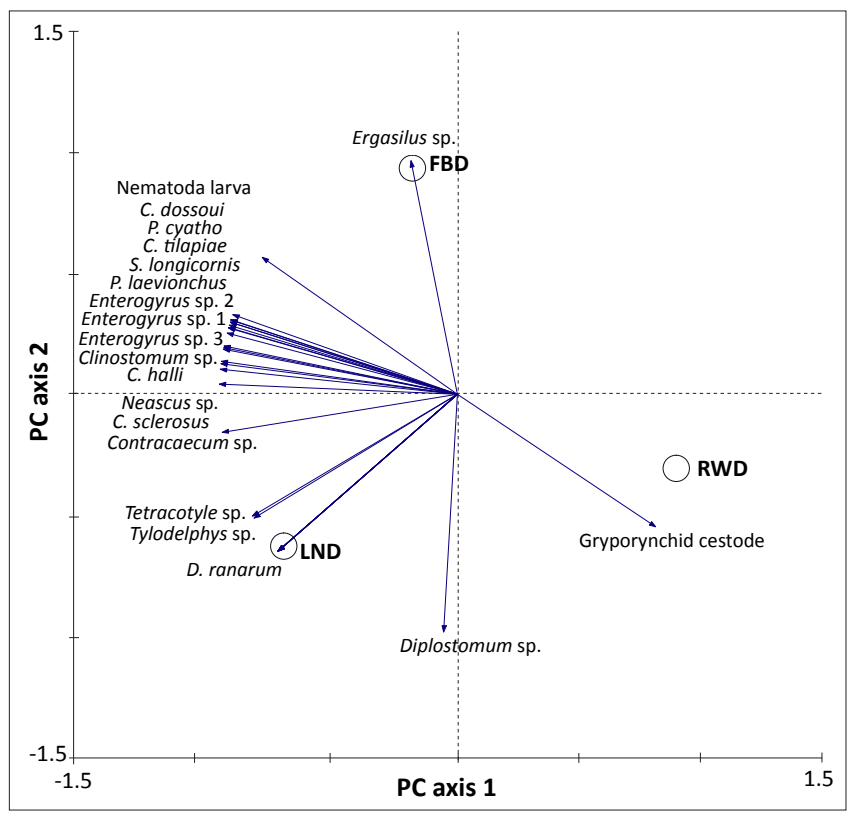

C., Cichlidogyrus spp.; P. cyatho., Paracamallanus cyathopharynx; S., Scutogyrus sp.; unid. nema., larvae of unidentified nematode; $D$., Dolops.

LND, Luphephe-Nwanedi Dams; FBD, Flag Boshielo Dam; RWD, return water dam.

FIGURE 6: A principal components analysis ordination biplot showing parasite species distribution based on abundance amongst sites.

organic pollution because they feed on organic particles (Sibley, Dixon \& Barton 2000). Kostarev (1980) found high numbers of Caryophyllaeus laticeps and attributed this to increased oligochaete populations where household sewage was discharged directly into reservoirs. Thus, the increased abundance of these intermediate hosts in this study may be due to the high organic enrichment of the sediments that are suitable for the oligochaete intermediate hosts (Sibley et al. 2000). In addition, a few endoparasitic cestodes are able to accumulate and tolerate higher levels of metal contaminants than their fish hosts (Retief, Avenant-Oldewage \& Du Preez 2007).

There were no substantial differences between the moderately polluted site and the reference site with regard to parasite component community species richness and diversity.
Prevalence values of some parasites (e.g. most monogeneans) were comparatively lower in fish from the reference site than in those from the moderately contaminated site, although no significant trends were detected. A large percentage of the differences between these two sites was due to higher mean abundances of most parasite species at the reference site. Thus, it appears that although moderate levels of contamination may affect parasite communities, the responses of parasites may be subtle or absent if a disturbance or pollution level is moderate (Marcogliese et al. 2006). It may be difficult to detect in part because the responses of all parasite species are integrated in community analyses (Kennedy 1997; Marcogliese 2005).

\section{Conclusion}

The results suggest that parasite species composition and richness of freshwater fish parasites are influenced by environmental factors. However, the responses of parasites may be subtle or absent if a disturbance or pollution level is moderate. Heteroxenous parasite species are transmitted through invertebrate and vertebrate hosts acting as intermediate or definitive hosts. Changes in the structure of a parasite community mirror differences in the composition of the aquatic species, such as macro-invertebrate fauna, commonly used as indicators of water quality. These findings also suggest that monoxenous parasite species decrease in numbers in disturbed environments, as they are directly exposed to the effects of water quality. Thus, parasite communities can be used as an early warning system for monitoring ecosystem degradation.

\section{Acknowledgements Competing interests}

The authors declare that they have no financial or personal relationship(s) which may have inappropriately influenced them in writing this paper.

\section{Authors' contributions}

W.J.L-P. (University of Limpopo) was the project leader, P.A.O. (University of Limpopo) the project co-leader and G.N.M-M. (University of Limpopo) was responsible for experimental design and performed most of the experiments and calculations.

\section{References}

Anderson, R.C., 1992, Nematode parasites of vertebrates: Their development and transmission, CAB International, Wallingford.

Ashton, P.J., 2010, 'The demise of the Nile crocodile (Crocodylus niloticus) as a keystone species for aquatic ecosystem conservation in South Africa: The case of the Olifants River', Aquatic Conservation: Marine and Freshwater Ecosystems 20, 489-493. http://dx.doi.org/10.1002/aqc.1132

Avenant-Oldewage, A., 2001, 'Protocol for the assessment of fish health based on the health index: Report and a manual for training of field workers to the Rand Water Board (report no. 2001/03/31)', report, Rand Water, Vereeniging.

Avenant, A., Van As, J.G. \& Loots, G.C., 1989, 'On the hatching and morphology of Dolops ranarum larvae (Crustacea: Branchiura)', Journal of Zoology (London) 217 511-519. http://dx.doi.org/10.1111/j.1469-7998.1989.tb02506.x

Barson, M., Bray, R.A., Ollevier, F. \& Huyse, T., 2008, 'Taxonomy and faunistics of the helminth parasites of Clarias gariepinus (Burchell, 1822), and Oreochromis mossambicus (Peters, 1852) from temporary pans and pools of the Save-Runde River floodplain, Zimbabwe', Comparative Parasitology 75, 228-240. http:// dx.doi.org/10.1654/4337.1 
Blanar, C.A., Munkittrick, K.R., Houlahan, J., MacLatchy, D.L. \& Marcogliese, D.J., 2009, 'Pollution and parasitism in aquatic animals: A meta-analysis of effect size', Aquatic Toxicology 93, 18-28. http://dx.doi.org/10.1016/j.aquatox.2009.03.002, Aquatic Toxicology

Bush, A.O., Lafferty, K.D., Lotz, J.M. \& Shostak, A.W., 1997, 'Parasitology meets ecology on its own terms: Margolis et al revisited', Journal of Parasitology 83, 575-583. on its own terms: Margolis et al. revisited', Journal
http://dx.doi.org/10.2307/3284227, PMid:9267395

Chibwana, F.D. \& Nkwengulila, G., 2010, 'Variation in the morphometrics of diplostomid metacercariae (Digenea: Trematoda) infecting the catfish, Clarias gariepinus in Tanzania', Journal of Helminthology 84, 61-70. http://dx.doi. gariepinus in Tanzania', Journal of Helminthology
org/10.1017/S0022149X09990083, PMid:19619367

De Villiers, S. \& Mkwelo, S.T., 2009, 'Has monitoring failed the Olifants River?', Water SA 35, 671-676.

Department of Water Affairs and Forestry, 1996, South African Water Quality Guidelines: Aquatic ecosystems, 2nd edn., Department of Water Affairs and Forestry, Pretoria.

Douëllou, L., 1993, 'Monogeneans of the genus Cichlidogyrus Paperna, 1960 (Dactylogyridae: Ancyrocephalinae) from cichlid fishes of Lake Kariba (Zimbabwe) with descriptions of five new species', Systematic Parasitology 25, 159-186. http://dx.doi.org/10.1007/BF00007007

Dzikowski, R., Paperna, I. \& Diamant, A., 2003, 'Use of fish parasite species richness indices in analyzing anthropogenically impacted coastal marine ecosystems', Helgoland Marine Research 57, 220-227. http://dx.doi.org/10.1007/s10152-0030138-2

Fausch, K.D., Lyons, J., Karr, J.R. \& Angermeier, P.L., 1990, 'Fish communities as indicators of environmental degradation', American Fisheries Society Symposium $8,123-144$

Kempster, P.L., Hattingh, W.H.J. \& Van Vliet, H.R., 1980, 'Summarized Water Quality Criteria', technical report (TR 108), Directorate of Water Affairs, Pretoria.

Kennedy, C.R., 1997, 'Freshwater fish parasites and environmental quality: An overview and caution', Parassitologia 39, 249-254.

Khalil, L.F., Jones, A. \& Bray, R.A. (eds.), 1994, Keys to the cestode parasites of vertebrates, CAB International, Wallingford.

Khan, R.A. \& Billiard, S.M., 2007, 'Parasites of winter flounder (Pleuronectes americanus) as an additional bioindicator of stress-related exposure to untreated pulp and paper mill effluent: A 5-year field study', Archives of Environmental Contamination and Toxicology 52, 243-250. http://dx.doi.org/10.1007/s00244006-0082-7, PMid:17160488

Kostarev, G.F., 1980, 'The effects of pollution on the fish parasite fauna in the Kama reservoirs', in Biologicheskie resursy vodoemov zapadnogo Urala, Mezhyuzovski Sborrnik Nauchnykh Trudov [Allow phonetic typing Biological resources of the waters west of the Urals], pp. 147-153, Perskii Gosudarstvennyi Universitet, Perskii.

Madanire-Moyo, G. \& Barson, M., 2010, 'Diversity of metazoan parasites of the African catfish Clarias gariepinus as indicators of pollution in a subtropical African river system', Journal of Helminthology 84, 216-227. http://dx.doi.org/10.1017/ S0022149X09990563, PMid:19761628

Magurran, A.E., 1988, Ecological diversity and its measurement, Princeton University Press, Princeton.
Marcogliese, D.J., 2005, 'Parasites of the superorganism: Are they indicators of ecosystem health?' International Journal for Parasitology 35, 705-716. http:// dx.doi.org/10.1016/j.ijpara.2005.01.015, PMid:15925594

Marcogliese, D.J., Gendron, A.D., Plante, C., Fournier, M. \& Cyr, D., 2006, 'Parasites of spottail shiners (Notropis hudsonius) in the St. Lawrence River: Effects of municipal effluents and habitat', Canadian Journal of Zoology 84, 1461-1481. http://dx.doi.org/10.1139/z06-088

Noorjahan, C.M., Dawood, S.S. \& Nausheen, D., 2003, 'Impact of dairy effluent on biochemical constituents of fish Oreochromis mossambica', Journal of Ecotoxicology \& Environmental Monitoring 13, 227-231.

Oberholster, P.J., Ashton, P.J. \& Macmillan, P.M., 2009, 'A water quality reconnaissance investigation of the Nwanedzi Dam, Limpopo Province', report (GWDMS 175044), CSIR (Natural Resources and the Environment), Pretoria.

Oros, M. \& Hanzelová, V., 2009, 'Re-establishment of the fish parasite fauna in the Tisa River system (Slovakia) after a catastrophic pollution event', Parasitology Research 104, 1497-1506. http://dx.doi.org/10.1007/s00436-009-1356-6, PMid:19214574

Pietrock, M. \& Marcogliese, D.J., 2003, 'Free-living endohelminth stages: At the mercy of environmental conditions', Trends in Parasitology 19, 293-299. http://dx.doi. org/10.1016/S1471-4922(03)00117-X

Pietrock, M., Meinelt, T. \& Marcogliese, D.J., 2008, 'Effects of cadmium exposure on embryogenesis of Stagnicola elodes (Mollusca, Gastropoda): Potential consequences for parasite transmission', Archives of Environmental Contamination and Toxicology 55, 43-48. http://dx.doi.org/10.1007/s00244-0079083-4, PMid:18166987

Retief, N.R., Avenant-Oldewage, A. \& Du Preez, H., 2007, 'Ecological aspects of the occurrence of Asian tapeworm, Bothriocephalus acheilognathi Yamaguti, 1934 infection in the largemouth yellowfish, Labeobarbus kimberleyensis (Gilchrist and Thompson, 1913) in the Vaal Dam, South Africa', Physics and Chemistry of the Earth 32, 1384-1390.

Schmidt, V., Zander, S., Koerting, W. \& Steinhagen, D., 2003, 'Parasites of the flounder Platichthys flesus (L.) from the German Bight, North Sea, and their potential use in ecosystem monitoring', Helgoland Marine Research 57, 236-251. http://dx.doi. org/10.1007/s10152-003-0159-x

Sibley, P.K., Dixon, F.G. \& Barton, D.R., 2000, 'Impact of bleached kraft pulp mill effluent on benthic community structure in relation to environmental factors', Journal of Aquatic Stress and Recovery 7, 229-246. http://dx.doi. org/10.1023/A:1009987123319

Somanath, V., 2003, 'Impact of tannery effluent on bioenergetics of fishes', Journal of Ecotoxicology \& Environmental Monitoring 13, 161-173.

South African Bureau of Standards, 2004, Draft 2: The Welfare of Animals in Laboratories, (SCS140.38D SANS 10386/3), South African Bureau of Standards, Pretoria.

Sures, B., 2008, 'Host-parasite interactions in polluted environments', Journal of Fish Biology 73, 2133-2142. http://dx.doi.org/10.1111/j.1095-8649.2008.02057.x

Ter Braak, C.J.F. \& Smilauer, P., 1998, CANOCO Reference Manual and User's Guide to CANOCO for Windows: Software for Canonical Community Ordination (Version 4.5), Microcomputer Power, Ithaca.

Thilakaratne, I.D.S.I.P., McLaughlin, J.D. \& Marcogliese, D.J., 2007, 'Effects of pollution and parasites on biomarkers of fish health in spottail shiners, Notropis hudsonius
(Clinton)', Journal of Fish Biology 71, 519-538. http://dx.doi.org/10.1111/j.10958649.2007.01511.x 